\title{
Heavy Metal Accumulation in Sediment and Removal Efficiency in the Stabilization Ponds with the Hydrocotyle ranunculoides Filter
}

\author{
María Custodio ${ }^{1 *}$, Edith Orellana-Mendoza', Richard Peñaloza', \\ Heidi De la Cruz-Solano', Wilfredo Bulege-Gutiérrez², Rebeca Quispe-Mendoza' \\ 1 Universidad Nacional del Centro del Perú, Centro de Investigación de Medicina en Altura y Medio Ambiente, \\ Av. Mariscal Castilla No. 3909-4089, Huancayo, Perú \\ 2 Universidad Continental, Av. San Carlos No. 1980, Huancayo, Perú \\ * Corresponding author's e-mail: mcustodio@uncp.edu.pe
}

\begin{abstract}
The heavy metal accumulation in the sediment and removal efficiency in stabilization ponds with Hydrocotyle ranunculoides filter were evaluated. Sediment and water were sampled in June, July and August 2018. The sediment sampling for each lagoon was conducted at three sites forming a composite sample. The water samples were collected in the tributary and effluent pipelines to determine the heavy metal concentration and removal efficiency by Hydrocotyle ranunculoides. The determination of heavy metals was performed with the method of atomic flame absorption spectrophotometry. The mean concentration of heavy metals in the sediment, in a descending order, was: $\mathrm{Fe}>\mathrm{Zn}>\mathrm{Pb}>\mathrm{Cu}>\mathrm{Cd}$. The concentrations of these metals ranged from 998.0 to 1365.02 , from 488.01 to 600.30, from 88.23 to 95.01 , from 1.47 to 1.53 and from 0.01 to $0.13 \mathrm{mg} / \mathrm{Kg}$, respectively. In the four stabilization ponds, the pollution factor values for $\mathrm{Cd}, \mathrm{Cu}$ and $\mathrm{Fe}$ qualified as low pollution factor. While for $\mathrm{Zn}$ and $\mathrm{Pb}$, they qualified as moderate pollution factors. The heavy metal removal rates from the water varied by metal
\end{abstract}

Keywords: heavy metals, stabilization ponds, Hydrocotyle ranunculoides, sediment quality, removal efficiency.

\section{INTRODUCTION}

The alteration of water quality is of great concern worldwide, due to the progressive deterioration of water bodies. The anthropogenic water pollution is a problem that has been aggravated by the generation of large amounts of wastewater and the excessive use of water in industry due to rapid population growth [Bhatia and Goyal, 2013]. The main pollutants entering water bodies are heavy metals from multiple anthropogenic sources. The contamination by heavy metals is one of the most dangerous problems for the human health and ecosystems because of their toxicity [Goncharuk, 2014; Gleason et al., 2016]. Heavy metals, unlike organic compounds, do not degrade and can be deposited in sediments, bioaccumulating and biomagnifing through the food web [Miretzky et al., 2004].
Heavy metals are of particular concern, because their removal is ineffective in the water treatment [de Kwaadsteniet et al., 2013]. Hence, many methods have been developed to remove the heavy metals from water (ion exchange, reverse osmosis, electrolysis, precipitation, adsorption among others). However, these methods can be very expensive for large volumes, low concentrations of heavy metals and high levels of cleanliness required. At present, in order to treat these contaminants, inexpensive and effective solutions are proposed, such as adsorbents. However, their use needs to be tested in the field in order to visualize their true viability [Joseph et al., 2019].

Another current solution that has been repeatedly validated and continues to give convincing results, is the phytoremediation with artificial wetlands, since its effect for decontamination, combined with microorganisms, is effective 
under varying conditions due to its adaptability to different environments and easy acclimatization [Salamanca et al., 2015]. In addition, these wetlands allow for the recovery of nutrients from wastewater; this makes them a promising technology for the nutrient recovery useful for agriculture [dhikari et al., 2015].

The biological or bioabsorption methods are recommended as the most economical and effective techniques for the removal of metal ions from aqueous solutions, phytoremediation being an alternative to reduce, remove, degrade or immobilize organic and inorganic chemicals [Módenes et al., 2009; Bahaa et al., 2019]. To date, several studies have examined the ability of some plants to capture metals from water and accumulate them in their biomass [Weiss et al., 2006].

Phytoremediation is an economical, nonintrusive and safe alternative to the conventional treatment techniques. This technique is increasingly accepted to remove heavy metals and reduce the water pollution through different mechanisms, such as phytoaccumulation, phytostabilization, phytodegradation, phytotransformation, phytovolatization and phytofiltration [Ali et al., 2013]. The removal of contaminants from water by phytofiltration can be performed by the absorption or adsorption processes through the roots of the plants (rhizofiltration), seedlings (blastofiltration) or shoots of the removed plants (caulofiltration) [Carolin et al., 2017]. In this context, the objective of the study was to evaluate the heavy metal accumulation in the sediment and the removal efficiency in stabilization ponds with the Hydrocotyle ranunculoides filter.

\section{MATERIAL AND METHODS}

\section{Description of study area and installation}

The stabilization ponds built for the treatment of domestic wastewater are located in the district of Sicaya at an altitude of 3232 m.a.s.l., with an area of $12600.00 \mathrm{~m}^{2}$. The average flow that the wetland receives is $21.6 \mathrm{~L} / \mathrm{s}$. This system is made up of a pre-treatment, a Parshall canal, a flow distribution system, two primary facultative lagoons, occupying a total area of $0.77 \mathrm{Ha}$ and two secondary facultative lagoons occupying a total area of $0.602 \mathrm{Ha}$, effluent collection channels and a perimeter fence. This system was implemented with the intention of complying with the maximum permissible limits (MPL) established by the Peruvian state, since all treated water flows into the Alca stream, a tributary of the Mantaro river.

The seeding of the H. ranunculoides macrophytes, was done after being collected from the Alcas stream, which is located northeast of the stabilization ponds. The results of the $H$. ranunculoides population growth were published in a preliminary study [Quispe et al., 2019]. In order to monitor the accumulation of heavy metals in the sediment, the composite samples were collected from the four stabilization ponds and to evaluate the suitability of the water for reuse, the samples were collected from 2 sites. The first site is located at the distribution box and the second at the confluence of the effluents before they are mixed with the waters of the receiving body. Monitoring was carried out in June, July and August 2018, twelve months after the installation of the macrophytes.

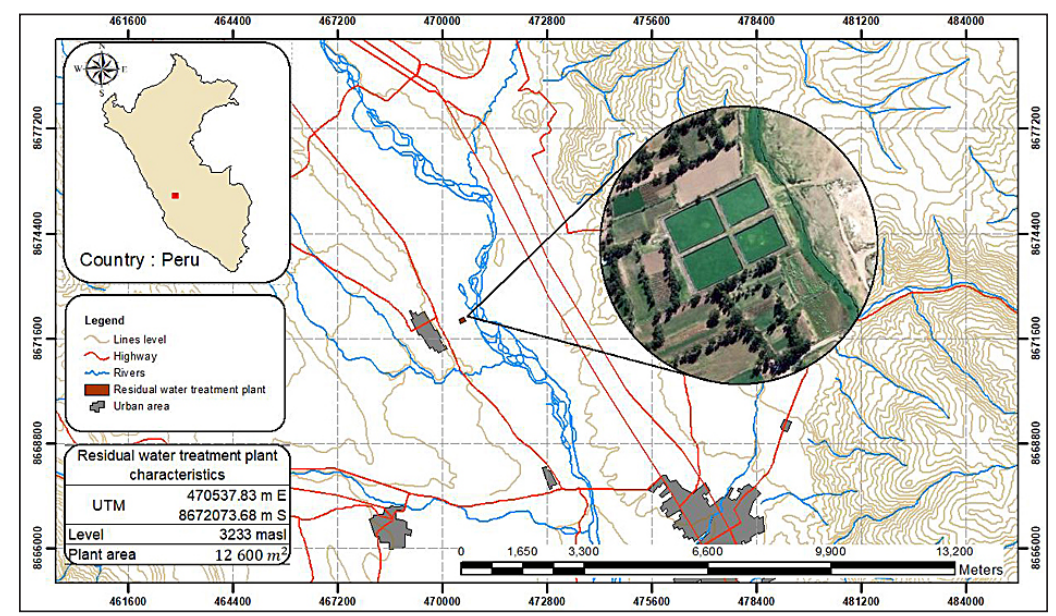

Figure 1. Location map of the stabilization ponds built for the treatment of domestic wastewater in the district of Sicaya, Huancayo 


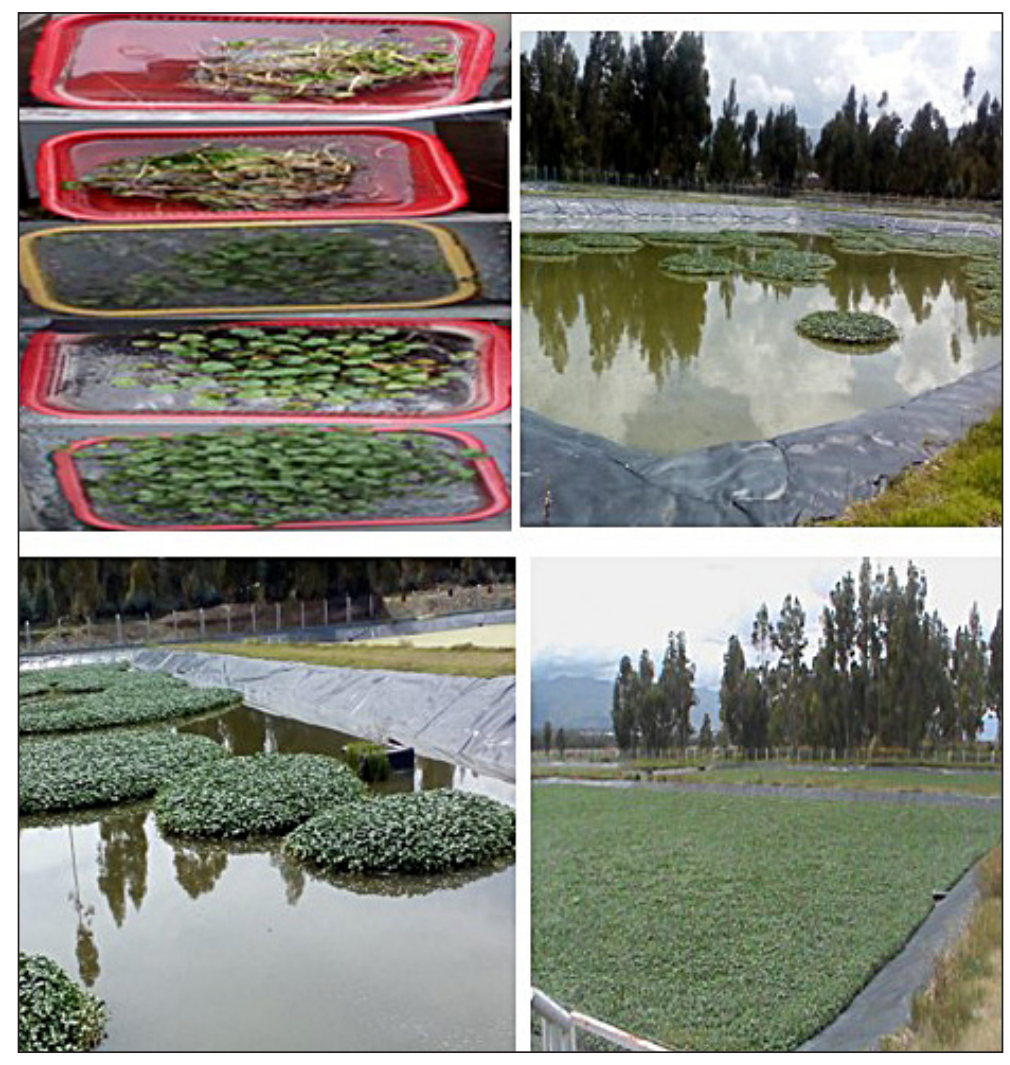

Figure 2. Hydrocotyle ranunculoides seeding process in the stabilization ponds built for domestic wastewater treatment in the district of Sicaya, Huancayo

\section{Sample collection and analysis}

The sediment and water were sampled in June, July and August 2018. The sediment sampling from each lagoon was conducted at three sites forming a composite sample (left, center, and right with respect to the direction of water flow). The sediment was sampled by a $10 \mathrm{~cm}$ diameter, $50 \mathrm{~cm}$ long stainless steel cylindrical dredge. The surface sediment was collected based on the criteria of other researchers who found no statistical difference in the sediment metal concentrations from various depth profiles in a HSSF $\mathrm{CW}$ treating domestic wastewater [Vymazal an Krása, 2003]. The water samples were collected in the tributary and effluent pipes to determine the concentration of heavy metals and the removal efficiency by $H$. ranunculoides. The collected samples were transported under refrigerated conditions to the laboratory for analysis.

The sediment samples were digested according to the USEPA 3051A method [USEPA, 2007] with some modifications. In brief, one gram of dry sample was transferred to a $150 \mathrm{ml}$ beaker, $2.5 \mathrm{ml}$ of nitric acid $\left(\mathrm{HNO}_{3}\right)$ and $10 \mathrm{ml}$ of hydrochloric acid $(\mathrm{HCl})$ were added, the beaker was covered with a clock moon and it was taken to digestion by means of the microwave-assisted method. The established digestion program was: 17 minutes at $120^{\circ} \mathrm{C}, 15$ minutes at $210^{\circ} \mathrm{C}$ and 30 minutes at $210^{\circ} \mathrm{C}$. After cooling, the digestion product was transferred to a $100 \mathrm{ml}$ phial and was measured with ultra-pure water. The sample was stored at $4^{\circ} \mathrm{C}$ and filtered prior to the analysis. The determination of heavy metals was performed with the method of atomic flame absorption spectrophotometry (air-acetylene) using the Perkin Elmer Analyst AA-6800 atomic absorption spectrometer, brand name Shimadzu.

\section{Data analysis}

The analysis of the heavy metal concentrations in the sediment and water from the $\mathrm{H}$. $\mathrm{ra}$ nunculoides filter stabilization ponds of the domestic wastewater treatment plant was performed through descriptive statistics expressed in tables and figures using the R software [Ajah et al., 2015]. As the water and sediment samples were taken at finite entry and exit points, it was necessary to check the concentration of the median of metals with the Mann Whitney method and the differences were considered significant at $\mathrm{P}<0.05$ [Villares et al., 2002]. The percentage removal 
was calculated by the proportion of the concentration of the metal assessed in the influent and effluent of the treatment plant [Joseph et al., 2019].

\section{Sediment quality indices}

The accumulation of heavy metals in $H$. ranunculoides filter stabilization pond sediment was evaluated with three sediment quality indices, including: pollution factor (CF), pollution load in$\operatorname{dex}(\mathrm{PLI})$ and geoaccumulation index $\left(\mathrm{I}_{\text {geo }}\right)$. The calculation method, application and contamination levels are shown in Table 1. The CF and the $\mathrm{I}_{\text {geo }}$ are obtained from the concentration of each element with its geochemical background reference. In turn, the calculation of the PLI involves comparing the concentration of elements with their background reference. Due to the absence of a background concentration of elements considered in the study, the IAEA-SL-1 material was used as reference values [International Atomic Energy Agency, 1999].

\section{RESULTS AND DISCUSSION}

\section{Contamination and accumulation of heavy metals in stabilization pond sediments}

Table 2 shows the descriptive statistics of heavy metal concentrations in the $H$. ranunculoides filter stabilization pond sediment. The behavior of the average heavy metal concentration, in a descending order, was: $\mathrm{Fe}>\mathrm{Zn}>\mathrm{Pb}>\mathrm{Cu}$ $>\mathrm{Cd}$. The concentrations of these metals ranged from 998.0 to $1365.02,488.01$ to $600.30,88.23$ to $95.01,1.47$ to 1.53 and 0.01 to $0.13 \mathrm{mg} / \mathrm{kg}$, respectively. However, the mean concentrations of $\mathrm{Cd}(0.08 \mathrm{mg} / \mathrm{Kg}), \mathrm{Cu}(1.50 \mathrm{mg} / \mathrm{Kg})$ and $\mathrm{Fe}$

Table 1. Sediment quality indices, formulas, characteristics and level of contamination

\begin{tabular}{|c|c|c|c|c|}
\hline Quality indices & Equation & Application & Significance & Contamination level \\
\hline $\begin{array}{l}\text { Contamination } \\
\text { factor } \\
(\mathrm{CF})\end{array}$ & $C F=\frac{\text { Cm muestra }}{C m \text { fondo }}$ & $\begin{array}{l}\text { Quantify the } \\
\text { degree of metal } \\
\text { contamination in } \\
\text { sediments based } \\
\text { on the } \\
\text { concentration in } \\
\text { the sample and at } \\
\text { the bottom [Manoj } \\
\text { and Padhy, 2014]. }\end{array}$ & $\begin{array}{l}\mathrm{C}_{\mathrm{m}} \text { sample, denotes } \\
\text { the concentration of } \\
\text { metal in the } \\
\text { sediment sample. } \\
\mathrm{C}_{\mathrm{m}} \text { background, } \\
\text { corresponds to the } \\
\text { metallic } \\
\text { concentration of the } \\
\text { sediment in its } \\
\text { natural } \\
\text { environment. }\end{array}$ & $\begin{array}{l}\mathrm{CF}<1 \text { (low CF) } \\
1 \leq \mathrm{CF}<3 \text { (moderate CF) } \\
3 \leq \mathrm{CF}<6 \text { (considerable CF) } \\
\mathrm{CF} \geq 6 \text { (very high CF) }\end{array}$ \\
\hline $\begin{array}{l}\text { Pollution load } \\
\text { index } \\
\text { (PLI) }\end{array}$ & $\mathrm{PLI}=(\mathrm{CF} 1 \mathrm{XCF} 2 \mathrm{XCF} 3 \mathrm{X}-\mathrm{CFn})^{2 / 5}=$ & $\begin{array}{l}\text { Determine metal } \\
\text { contamination in } \\
\text { lake sediments } \\
\text { [Tomlinson et al., } \\
\text { 1980). }\end{array}$ & $\begin{array}{l}\text { " } n \text { " represents the } \\
\text { number of metals. } \\
C F \text {, is the } \\
\text { contamination } \\
\text { factor. } \\
\mathrm{PLI} \text {, is the global } \\
\text { value of } \\
\text { contamination by } \\
\text { metal species. } \\
\text { Calculated from the } \\
\text { CF of each metal. }\end{array}$ & $\begin{array}{l}\text { PLI = } 0 \text { (perfection) } \\
\text { PLI = } 1 \text { (baseline levels of } \\
\text { pollutants present) } \\
\text { PLI > } 1 \text { (progressive } \\
\text { deterioration of site) }\end{array}$ \\
\hline $\begin{array}{c}\text { Geoaccumulatio } \\
\mathrm{n} \text { index } \\
\left(\mathrm{I}_{\text {geo }}\right)\end{array}$ & $I_{g e o}=\log 2\left(\frac{C n}{1.5 B n}\right)$ & $\begin{array}{l}\text { Calculate the } \\
\text { contamination of } \\
\text { the sediments by } \\
\text { comparing the } \\
\text { concentrations of } \\
\text { the metal with its } \\
\text { geochemical } \\
\text { background } \\
\text { [Müller, 1979]. In } \\
\text { addition, the Igeo } \\
\text { is important in } \\
\text { determining the } \\
\text { quality of sediment } \\
\text { at each sampling } \\
\text { site. }\end{array}$ & $\begin{array}{l}C_{n} \text {, is the metal } \\
\text { concentration in the } \\
\text { sediment. } \\
B_{n} \text {, is the metal } \\
\text { concentration at the } \\
\text { bottom. For a } \\
\text { correction of the } \\
\text { natural variations or } \\
\text { the anthropogenic } \\
\text { effect to the CF } \\
\text { equation a constant } \\
\text { value is multiplied } \\
\text { (1.5). }\end{array}$ & $\begin{array}{l}\text { Igeo }<0 \text { Class } 0 \\
\text { (uncontaminated) } \\
0<\text { Igeo }<1 \text { Class } 1 \\
\text { (uncontaminated to moderately } \\
\text { contaminated) } \\
1<\text { Igeo }<2 \text { Class } 2 \\
\text { (moderately } \\
\text { contaminated) } \\
2<\text { Igeo }<3 \text { Class } 3 \\
\text { (moderately to heavily } \\
\text { contaminated) } \\
3<\text { Igeo }<4 \text { Class } 4 \text { (heavily } \\
\text { contaminated) } \\
4<\text { Igeo }<5 \text { Class } 5 \text { (heavily to } \\
\text { extremely contaminated) } \\
\text { Igeo } \geq 5 \text { Class } 6 \text { (extremely } \\
\text { contaminated) }\end{array}$ \\
\hline
\end{tabular}


Table 2. Descriptive statistics of heavy metal concentrations in sediment of stabilization pond with Hydrocotyle ranunculoides filter $(\mathrm{mg} / \mathrm{Kg})$

\begin{tabular}{|c|c|c|c|c|c|c|}
\hline \multirow{2}{*}{ Sample } & $\begin{array}{c}\text { Descriptive } \\
\text { statistics }\end{array}$ & $\mathrm{Cd}$ & $\mathrm{Cu}$ & $\mathrm{Fe}$ & $\mathrm{Zn}$ & $\mathrm{Pb}$ \\
\hline \multirow{3}{*}{ Sedimento } & Mean & 0.08 & 1.50 & 1172.24 & 556.10 & 91.76 \\
\cline { 2 - 7 } & $\mathrm{SD}$ & 0.06 & 0.03 & 184.21 & 59.84 & 3.40 \\
\cline { 2 - 7 } & Maximum & 0.13 & 1.53 & 1365.02 & 600.30 & 95.01 \\
\cline { 2 - 7 } & Minimum & 0.01 & 1.47 & 998.00 & 488.01 & 88.23 \\
\hline \multirow{2}{*}{$\begin{array}{c}\text { Reference material } \\
\text { IAEA-SL-1 (mg/Kg) }\end{array}$} & Mean & 0.26 & 30 & 67400 & 223 & 37.7 \\
\cline { 2 - 7 } & I.C. 95\% & $0.21-0.31$ & $24-36$ & $65700-69100$ & $213-233$ & $30.3-45.1$ \\
\hline CISQG & & 0.70 & 18.70 & NP & 124 & 30.20 \\
\hline
\end{tabular}

IAEA: International Atomic Energy Agency CISQG: Canadian interim sediment quality guideline

$(1172.24 \mathrm{mg} / \mathrm{Kg})$ did not exceed the mean values of the IAEA-SL-1 reference material [International Atomic Energy Agency, 1999] nor the values set by the Canadian Interim Sediment Quality Guidelines (CISQG) stipulated by the Canadian Council of Ministers of the Environment [Canadian Council of Ministers of the Environment, 2001]. $\mathrm{Zn}$ and $\mathrm{Pb}$ did not follow this behavior, as they exhibited mean values that greatly exceeded the mean values of the IAEA-SL-1 reference material and the CISQG values (Figure 3), revealing higher enrichment by these metals. However, the concentrations of heavy metals in the sediments of the stabilization ponds evaluated are lower than the concentrations of these metals in the wetlands that treat the water from the mining industry [Leung et al., 2017].

Table 3 shows the values of pollution factor (CF), pollution load index (PLI) and heavy metal geoaccumulation factor in the sediment obtained from stabilization ponds with $H$. ranunculoides.
In all four ponds, the $\mathrm{CF}$ values for $\mathrm{Cd}, \mathrm{Cu}$ and Fe qualified as low pollution factor $(\mathrm{CF}<1)$. In turn, for $\mathrm{Zn}$ and $\mathrm{Pb}$, they qualified as moderate pollution factors $(1 \leq \mathrm{CF}<3)$. The PLI indicated that there is no appreciable contamination by the heavy metals evaluated with the values ranging from 0.1826 to 0.3177 . The Igeo values of the metals evaluated were $0>\mathrm{I}_{\text {geo }}<1$, indicating that the sites show signs of contamination. These results are due to the shorter life span of these stabilization ponds, the type of wastewater they receive and the role of metal retention through the filtration of this macrophyte and adsorption processes [Leung et al., 2017].

\section{Heavy metal removal efficiency by Hydrocotyle ranunculoides}

Table 4 shows the descriptive statistics of heavy metals in $H$. ranunculoides filter stabilization pond water and removal efficiency. The

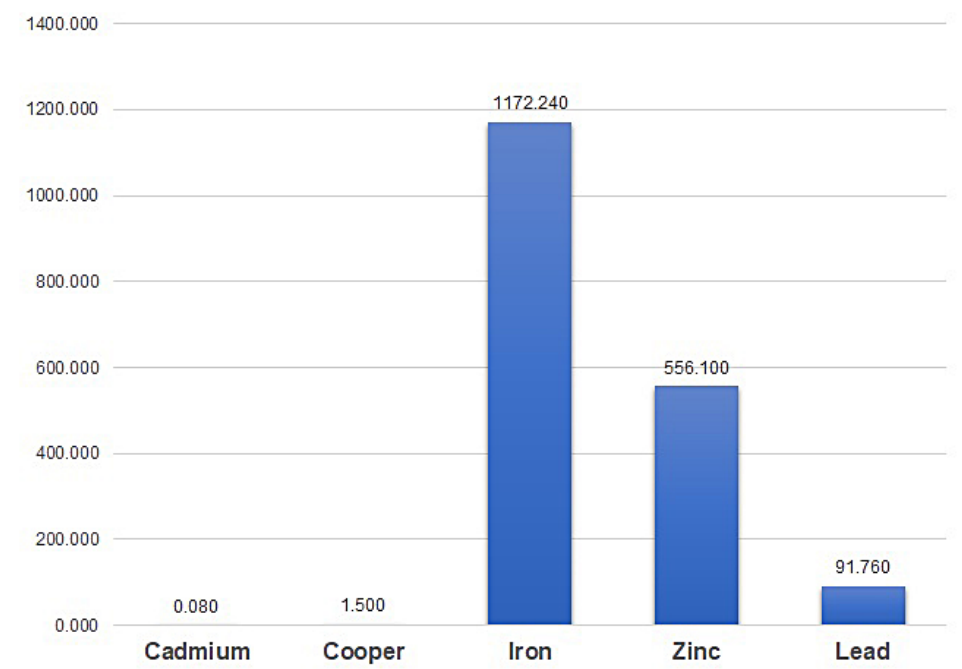

Figure 3. Mean heavy metal concentration in the stabilization pond sediment with the Hydrocotyle ranunculoides filter 
Table 3. Sediment quality indices of the stabilization ponds with Hydrocotyle ranunculoides

\begin{tabular}{|c|c|c|c|c|c|c|c|c|c|c|c|}
\hline \multirow{2}{*}{$\begin{array}{l}\text { Sampling } \\
\text { site }\end{array}$} & \multicolumn{5}{|c|}{ Contamination factor (CF) } & \multirow{2}{*}{ PLI } & \multicolumn{5}{|c|}{ Geoaccumulation index $\left(I_{\text {geo }}\right)$} \\
\hline & $\mathrm{Cd}$ & $\mathrm{Cu}$ & $\mathrm{Fe}$ & $\mathrm{Zn}$ & $\mathrm{Pb}$ & & $\mathrm{Cd}$ & $\mathrm{Cu}$ & $\mathrm{Fe}$ & $\mathrm{Zn}$ & $\mathrm{Pb}$ \\
\hline $\mathrm{P} 1$ & 0.4808 & 0.0490 & 0.0203 & 2.6919 & 2.5203 & 0.3177 & 0.0965 & 0.0098 & 0.0041 & 0.5402 & 0.5058 \\
\hline $\mathrm{P} 2$ & 0.3769 & 0.0496 & 0.0171 & 2.1884 & 2.3403 & 0.2773 & 0.0756 & 0.0100 & 0.0034 & 0.4392 & 0.4697 \\
\hline P3 & 0.0423 & 0.0511 & 0.0148 & 2.6009 & 2.4412 & 0.1826 & 0.0085 & 0.0102 & 0.0030 & 0.5220 & 0.4899 \\
\hline $\mathrm{P} 4$ & 0.0385 & 0.0500 & 0.0174 & 2.5000 & 2.4345 & 0.1826 & 0.0077 & 0.0100 & 0.0035 & 0.5017 & 0.4886 \\
\hline
\end{tabular}

Table 4. Descriptive statistics of the heavy metal concentrations in water and removal efficiency of the stabilization pond with the Hydrocotyle ranunculoides filter $(\mathrm{mg} / \mathrm{L})$

\begin{tabular}{|c|c|c|c|c|c|c|}
\hline Sample & $\begin{array}{c}\text { Descriptive } \\
\text { statistics }\end{array}$ & $\mathrm{Cd}$ & $\mathrm{Cu}$ & $\mathrm{Fe}$ & $\mathrm{Zn}$ & $\mathrm{Pb}$ \\
\hline \multirow{4}{*}{ Affluent } & Mean & 0.17 & 3.22 & 21.45 & 19.33 & 0.43 \\
\cline { 2 - 7 } & $\mathrm{SD}$ & 0.04 & 0.43 & 1.5 & 1.27 & 0.06 \\
\cline { 2 - 7 } & Maximum & 0.21 & 3.55 & 23.02 & 20.21 & 0.48 \\
\cline { 2 - 7 } & Minimum & 0.13 & 2.73 & 20.02 & 17.87 & 0.36 \\
\hline \multirow{4}{*}{ Effluent } & Mean & 0.09 & 1.50 & 12.10 & 11.82 & 0.20 \\
\cline { 2 - 7 } & SD & 0.02 & 0.35 & 1.68 & 3.10 & 0.04 \\
\cline { 2 - 7 } & Maximum & 0.11 & 1.84 & 13.4 & 15.4 & 0.24 \\
\cline { 2 - 7 } & Minimum & 0.07 & 1.14 & 10.2 & 9.87 & 0.16 \\
\hline \multicolumn{2}{|c|}{$\%$ removal } & $51 \%$ & $47 \%$ & $56 \%$ & $61 \%$ & $46 \%$ \\
\hline
\end{tabular}

concentration of cadmium in the influent varied from 0.13 to $0.21 \mathrm{mg} / \mathrm{L}$, copper from 2.73 to $3.55 \mathrm{mg} / \mathrm{L}$, iron from 20.02 to $23.02 \mathrm{mg} / \mathrm{L}$, zinc 17.87 to $20.21 \mathrm{mg} / \mathrm{L}$ and lead from 0.36 to $0.48 \mathrm{mg} / \mathrm{L}$. In turn, the effluent concentrations of cadmium, copper, iron, zinc, and lead ranged from 0.07 to $0.11 \mathrm{mg} / \mathrm{L}, 1.14$ to $1.84 \mathrm{mg} / \mathrm{L}, 10.2$ to $13.4 \mathrm{mg} / \mathrm{L}, 9.87$ to $15.4 \mathrm{mg} / \mathrm{L}$, and 0.16 to $0.24 \mathrm{mg} / \mathrm{L}$, respectively. In addition, the concentrations of heavy metals recorded in the effluent were lower than the concentrations in the influent and were arranged as follows: $\mathrm{Fe}>\mathrm{Zn}>\mathrm{Cu}>\mathrm{Pb}>$ $\mathrm{Cd}$. The percentages of heavy metal removal from the water varied by metal. Zn was the metal with the highest percentage of removal (61\%) followed by $\mathrm{Fe}(56 \%), \mathrm{Cd}(51 \%), \mathrm{Cu}(47 \%)$ and $\mathrm{Pb}(46 \%)$ (Figure 4). This heavy metal removal efficiency is due to the formation of insoluble compounds with sulfides, phosphates, hydroxides and carbonate [Khan et al., 2009]. Moreover, it results from the processes of mechanical retention (suspended matter), complexation (organic matter), adsorption - desorption (oxides of Fe and Mn, clay particles, root surfaces, etc.) or absorption (vegetables, macrofauna and microorganisms) [Truu et al., 2009; Liang et al., 2017;Castro and Donati, 2019].

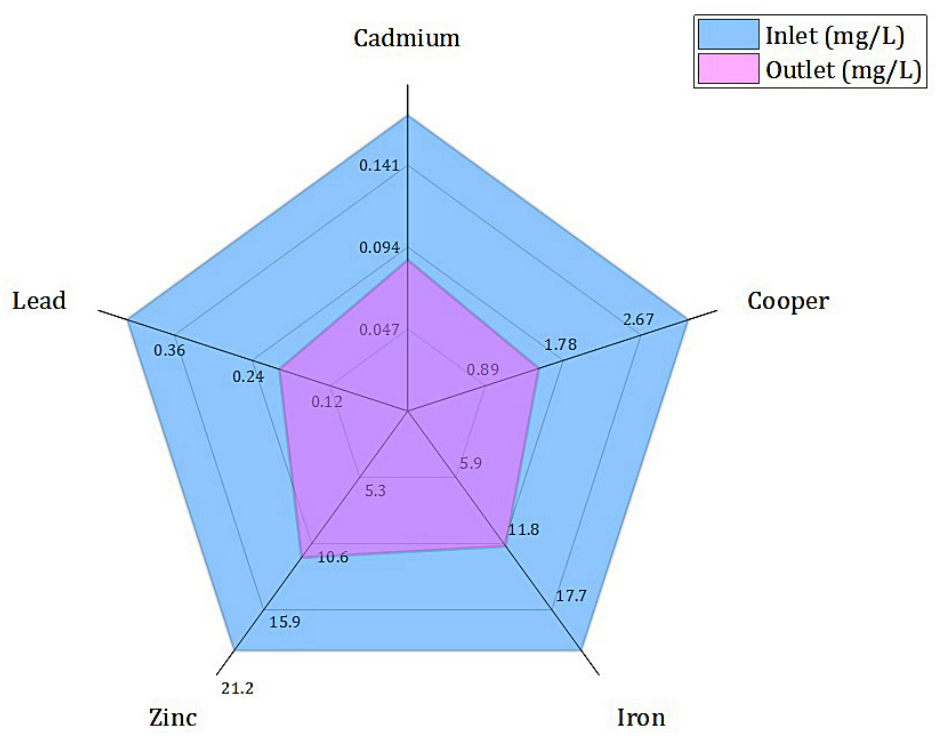

Figure 4. Heavy metal removal from stabilization pond water with Hydrocotyle ranunculoides filter. 
The results obtained are also supported by other researchers who evaluated the potential bioaccumulator Hydrocotyle ranunculoides under laboratory conditions revealing that this macrophyte could be a potential bioaccumulator of heavy metals [Rizzo et al., 2012]. However, the studies on the removal capacity of heavy metals by $H$. ranunculoides in the systems and under conditions similar to the present study are scarce. Additionally, the studies that address the accumulation of heavy metals in stabilization pond sediments with this macrophyte.

The heavy metal removal efficiencies of this study are lower than those reported by other researchers on the treatment of municipal and industrial wastewater using horizontal subsurface flow wetlands with vegetation [Galletti et al., 2010; Hadad et al., 2018].

\section{CONCLUSIONS}

This preliminary research on the accumulation of heavy metals in the sediment of the stabilization ponds with the Hydrocotyle ranunculoides filter in theee areas above 3000 m.a.s.l., reveals that $40 \%$ of the heavy metals $(\mathrm{Zn}$ and $\mathrm{Pb})$ detected in the sediment have the concentrations that greatly exceed the average values of the IAEA-SL-1 reference material and the CISQG. Meanwhile, $60 \%$ of the metals evaluated did not exceed the average values of the reference material. This result indicates that Hydrocotyle ranunculoides is a good contaminant filter with a high capacity to store and remove $\mathrm{Zn}$, $\mathrm{Cu}$ and $\mathrm{Fe}$ as biomass. The use of macrophytes to reduce the concentration of heavy metals in the sediment from stabilization ponds is still at an early stage in high Andean cities in central Peru.

\section{Acknowledgements}

The authors express their gratitude to the Water Research Laboratory of the Universidad Nacional del Centro del Perú for allowing us to develop one of the phases of this study. Also, to Stiven Rosales and José Julcani for their valuable collaboration.

\section{REFERENCES}

1. Adhikari, U., Harrigan, T., \& Reinhold, D.M. 2015. Use of duckweed-based constructed wetlands for nutrient recovery and pollutant reduction from dairy wastewater. Ecological Engineering, 78, 6-14. https://doi.org/10.1016/j.ecoleng.2014.05.024

2. Ajah, K.C., Ademiluyi, J., \& Nnaji, C.C. 2015. Spatiality, seasonality and ecological risks of heavy metals in the vicinity of a degenerate municipal central dumpsite in Enugu, Nigeria. Journal of Environmental Health Science and Engineering. https://doi. org/10.1186/s40201-015-0168-0

3. Ali, H., Khan, E., \& Anwar, M. 2013. Phytoremediation of heavy metals - Concepts and applications. Chemosphere, 91, 869-881.

4. Bahaa, S., Al-Baldawi, I., Rasheed, S., \& Abdullah, S.R.S. 2019. Biosorption of Heavy Metals from Synthetic Wastewater by Using Macro Algae Collected from Iraqi Marshlands. Journal of Ecological Engineering, 20(11), 18-22. https://doi. org/10.12911/22998993/113415

5. Canadian Council of Ministers of the Environment. 2001. Canadian Sediment Quality Guidelines for the Protection of Aquatic Life - Polychlorinated Dibenzo- p-Dioxins and Polychlorinated Dibenzofurans (PCDD/Fs). In Canadian Council of Ministers of the Environment (Ed.), Canadian environmental quality guidelines, 1999, Canadian Council of Ministers of the Environment, Winnipeg. (pp. 1-6). Canadian Council of Ministers of the Environment 2001.

6. Carolin, C.F., Kumar, P.S., Saravanan, A., Joshiba, G.J., \& Naushad, M. 2017. Efficient techniques for the removal of toxic heavy metals from aquatic environment: A review. Journal of Environmental Chemical Engineering, 5(3), 2782-2799. https:// doi.org/10.1016/j.jece.2017.05.029

7. Castro, C., \& Donati, E.R. 2019. Innovative Biomining: Microorganisms and Bioremediation. Heavy Metals in the Environment. https://doi.org/10.1201/ b22013-8

8. de Kwaadsteniet, M., Dobrowsky, P.H., van Deventer, A., Khan, W., \& Cloete, T.E. 2013. Domestic Rainwater Harvesting: Microbial and Chemical Water Quality and Point-of-Use Treatment Systems. Water, Air, \& Soil Pollution, 224(7), 1629. https:// doi.org/10.1007/s11270-013-1629-7

9. Galletti, A., Verlicchi, P., \& Ranieri, E. 2010. Removal and accumulation of $\mathrm{Cu}, \mathrm{Ni}$ and $\mathrm{Zn}$ in horizontal subsurface flow constructed wetlands: Contribution of vegetation and filling medium. Science of the Total Environment, 408(21), 5097-5105. https://doi.org/10.1016/j.scitotenv.2010.07.045

10. Gleason, K.M., Valeri, L., Shankar, A.H., Hasan, M.O.S.I., Quamruzzaman, Q., Rodrigues, E.G., ... Mazumdar, M. 2016. Stunting is associated with blood lead concentration among Bangladeshi children aged 2-3 years. Environmental Health, 15(1), 103. https://doi.org/10.1186/s12940-016-0190-4

11. Goncharuk, V.V. 2014. Role of Water in Human Life. In Drinking Water (pp. 1-16). Cham: 
Springer International Publishing. https://doi. org/10.1007/978-3-319-04334-0_1

12. Hadad, H.R., Mufarrege, M. de las M., Di Luca, G.A., \& Maine, M.A. 2018. Long-term study of $\mathrm{Cr}$, Ni, $\mathrm{Zn}$, and $\mathrm{P}$ distribution in Typha domingensis growing in a constructed wetland. Environmental Science and Pollution Research, 25(18), 18130-18137. https://doi.org/10.1007/s11356-018-2039-6

13. International Atomic Energy Agency, 1999. Reference Sheet for IAEA-SL-1 Trace and miner elements in lake sediments. Retrieved from https:// nucleus.iaea.org/rpst/Documents/rs_iaea-sl-1.pdf

14. Joseph, L., Jun, B.M., Flora, J.R.V., Park, C.M., \& Yoon, Y. 2019. Removal of heavy metals from water sources in the developing world using low-cost materials: A review. Chemosphere, 229, 142-159. https://doi.org/10.1016/j.chemosphere.2019.04.198

15. Khan, S., Ahmad, I., Shah, M.T., Rehman, S., \& Khaliq, A. 2009. Use of constructed wetland for the removal of heavy metals from industrial wastewater. Journal of Environmental Management, 90(11), 3451-3457. https://doi.org/10.1016/j. jenvman.2009.05.026

16. Leung, H.M., Duzgoren-Aydin, N.S., Au, C.K., Krupanidhi, S., Fung, K.Y., Cheung, K.C., ... Tsui, M.T.K. 2017. Monitoring and assessment of heavy metal contamination in a constructed wetland in Shaoguan (Guangdong Province, China): bioaccumulation of $\mathrm{Pb}, \mathrm{Zn}, \mathrm{Cu}$ and $\mathrm{Cd}$ in aquatic and terrestrial components. Environmental Science and Pollution Research International, 24(10), 9079-9088. https://doi.org/10.1007/s11356-016-6756-4

17. Liang, Y., Zhu, H., Bañuelos, G., Yan, B., Zhou, Q., Yu, X., \& Cheng, X. 2017. Constructed wetlands for saline wastewater treatment: A review. Ecological Engineering, 98, 275-285. https://doi. org/10.1016/j.ecoleng.2016.11.005

18. Manoj, K., \& Padhy, P.K. 2014. Distribution, Enrichment and Ecological Risk Assessment of Six Elements in Bed Sediments of a Tropical River, Chottanagpur Plateau: A Spatial and Temporal Appraisal. Journal of Environmental Protection, 5(November), 1419-1434. https://doi.org/10.4236/ jep. 2014.514136

19. Módenes, A.N., Thomé, L.P., Palácio, S.M., Trigueros, D.E.G., Oliveira, A.P., \& Szymanski, N. 2009. Study of the bioaccumulation kinetic of lead by living aquatic macrophyte Salvinia auriculata, 150,
316-322. https://doi.org/10.1016/j.cej.2009.01.004

20. Müller, G. 1979. Heavy metals in the sediment of the Rhine-Changes seitt. 1971. Umschan, 79, 778-783.

21. Quispe, R., Soto, M., Ingaruca, E., Bulege, W., \& Custodio, M. 2019. Optimization of the Operation of a Municipal Wastewater Treatment Plant with Hydrocotyle ranunculoides. Journal of Ecological Engineering, 20(9), 228-236. https://doi. org/10.12911/22998993/112486

22. Rizzo, P.F., Bres, P.A., Crespo, D.E., Arreghini, S., Serafini, R.J.M., \& Fabrizio de Iorio, A.R. 2012. Remediation of feedlot effluents using aquatic plants. Revista de La Facultad de Ciencias Agrarias, 44(2), 47-64.

23. Salamanca, E.J. P., Madera-Parra, C.A., Avila-Williams, C.A., Rengifo-Gallego, A.L., \& Ríos, D.A. 2015. Phytoremediation Using Terrestrial Plants. In Phytoremediation (pp. 305-319). Cham: Springer International Publishing. https://doi.org/10.1007/ 978-3-319-10969-5_25

24. Tomlinson, D.L., Wilson, J.G., Harris, C.R., \& Jeffrey, D.W. 1980. Problems in the assessment of heavy-metal levels in estuaries and the formation of a pollution index. Helgolander Meeresunters, 33, 566-575.

25. Truu, M., Juhanson, J., \& Truu, J. 2009. Microbial biomass, activity and community composition in constructed wetlands. Science of the Total Environment, 407(13), 3958-3971. https://doi. org/10.1016/j.scitotenv.2008.11.036

26. USEPA. (2007). Framework for Metals Risk Assessment. EPA 120/R-07/001. Environmental Protection.

27. Villares, R., Puente, X., \& Carballeira, A. 2002. Seasonal variation and background levels of heavy metals in two green seaweeds. Environmental Pollution, 119(1), 79-90. https://doi.org/10.1016/ S0269-7491(01)00322-0

28. Vymazal, J., \& Krása, P. 2003. Distribution of Mn, Al, $\mathrm{Cu}$ and $\mathrm{Zn}$ in a constructed wetland receiving municipal sewage. Water Science and Technology, 48(5), 299-306. https://doi.org/10.2166/wst.2003.0336

29. Weiss, J., Hondzo, M., Biesboer, D., \& Semmens, M. 2006. International Journal of Phytoremediation Laboratory Study of Heavy Metal Phytoremediation by Three Wetland Macrophytes, (November 2014), 37-41. https://doi. org/10.1080/15226510600846798 